\title{
Na quebrada, a parceria é mais forte - juventude hip-hop: relacionamento e estratégias contra a discriminação na periferia do Distrito Federal
}

Breitner Luiz Tavares

Curso: Doutorado em Sociologia

Data da defesa: 15 de maio de 2009

Orientador: Prof. Dr. Brasilmar Ferreira Nunes

\section{Resumo}

Esta tese propõe a abordagem do problema referente à marginalização da juventude de comunidades localizadas na periferia do Distrito Federal, tendo por referência algumas de suas cidades, mais precisamente, Ceilândia. O recorte analítico para se observar o tema é o estilo de vida em torno da cultura hip-hop praticada por jovens no Distrito Federal, compreendido como mecanismo produtor de suas orientações coletivas e visão de mundo. Em termos de objetivos, esta tese visa observar elementos referentes às orientações coletivas promovidas por esses jovens no sentido da construção de um estilo de vida em torno da cultura jovem como fator preponderante para a configuração geracional. Além disso, este estudo almeja, ainda, verificar como o jovem constrói vínculos de sociabilidade, a partir da sexualidade masculina, voltados para o relacionamento afetivo, que expressa a construção de papéis sociais sexuais. Em seguida, a narrativa sobre experiências discriminatórias será a base para uma análise do imaginário racial dessa juventude que sofre com a discriminação, mas estabelece suas próprias estratégias para enfrentá-la.

Palavras-chave: juventude; gerações; método documentário; estilo de vida; hip-hop; masculinidade; genero; raça. 